\title{
Evolução do Mercado Brasileiro de Biodiesel sob a Ótica dos Leilóes Promovidos pela ANP: 2005 a 2014
}

\author{
Laila Cristina Gonçalves Silva Amaral² e Yolanda Vieira de $\mathrm{Abreu}^{3}$
}

\begin{abstract}
Resumo: O Programa Nacional de Produção e Uso de Biodiesel (PNPB) foi criado com o intuito de introduzir o biodiesel na matriz energética brasileira. A comercialização do biodiesel é realizada, principalmente, por meio dos leilóes regulamentados pela Agência Nacional do Petróleo, Gás Natural e Biocombustíveis (ANP), com a finalidade de assegurar o adequado funcionamento do sistema de estoques, advindo do progressivo aumento da mistura obrigatória do biodiesel ao diesel. Este trabalho tem como objetivo identificar os fatores que influenciaram a evolução do mercado brasileiro de biodiesel sob a ótica da oferta deste produto nos leilões públicos realizados pela ANP. Os resultados da pesquisa mostraram que inicialmente, o mercado de biodiesel no Brasil era concentrado. Porém, com o aumento do número de empresas participantes, do percentual de mistura obrigatória e o aprimoramento na legislação sobre o PNPB e dos leilóes, este foi se transformando em moderadamente concentrado. Contatou-se, também, que o setor de biodiesel é caracterizado pelo oligopólio puro, em que os produtos não são diferenciados, algumas empresas são responsáveis pela maior parte da produção e há barreiras à entrada devido às exigências que devem ser cumpridas, pelas empresas, para participar dos leilões.
\end{abstract}

Palavras-chaves: Biodiesel; Leilões públicos; Concentração de mercado; Fatores de influência.

Abstract: The National Biodiesel Production and Use Program (PNPB) was created so as to introduce biodiesel in the Brazilian energy matrix. Biodiesel is mainly commercialized through auctions regulated by the National Oil, Natural Gas and Biofuel Agency (ANP) to ensure the adequate functioning of the stock system due to the progressive increase in the mandatory adding of biodiesel to diesel fuel. The aim of this study was to identify the factors influencing the evolution of the Brazilian biodiesel market from a supply perspective as a result of the public auctions held by the ANP. The results of the study showed that,

1. Data de submissão: 14 de março de 2016. Data de aceite: 14 de agosto de 2016.

2. Universidade Federal do Tocantins, Palmas, Tocantins, Brasil. E-mail: lailakrys@ hotmail.com

3. Universidade Federal do Tocantins, Palmas, Tocantins, Brasil. E-mail: yolanda@uft.edu.br 
initially, the Brazilian biodiesel market is concentrated. However, with the increase in the number of participating companies, the percentage of mandatory mixture and the improvements in the legislation regarding the PNPB and the auctions, the market has become moderately concentrated. The study also found that the biodiesel sector may be characterized as pure oligopoly, where there are no differences among products, few companies are responsible for most of the production and there are barriers to entry due to the requirements that must be met by the companies to participate in the auctions.

Key-words: Biodiesel; Public auctions; Market concentration; Factors of influence.

\section{Introdução}

A elevada preocupação do Estado e da sociedade com a questão ambiental, em especial àquelas ligadas à emissão de gases do efeito estufa, fez com que houvesse uma busca intensiva por fontes alternativas de energia, sucedâneas ao carbono fóssil. Diante disso, aumentou-se cada vez mais a demanda pela produção e consumo de energia renovável, proveniente de recursos naturais capazes de se ressurgirem, como as energias eólica, solar, hidrelétrica e advinda da biomassa, como o etanol e o biodiesel (CASTELLANELLI, 2008).

Considerado um dos biocombustíveis protagonista para exercer o papel substituto do diesel mineral, o biodiesel não é apenas um combustível ambientalmente mais adequado, substituto parcial ou total de combustíveis de origem fóssil úteis na geração de energia e redutor de fontes emissoras de enxofres e outros poluentes. Ademais, é um combustível biodegradável derivado de fontes naturais e renováveis que pode ser usado em qualquer motor de ciclo diesel, e um propulsor da inclusão social a partir do incentivo à participação da agricultura familiar no seu processo de produção (SILVEIRA, SILVA e SILVA JÚNIOR, 2010).

No Brasil, a comercialização do produto é realizada, principalmente, por meio de leilóes que têm por objetivo conferir suporte econômico à sua cadeia produtiva e contribuir para o atendi- mento das diretrizes do PNPB. Além disso, este sistema de comercialização assegura o adequado funcionamento do Sistema Nacional de Estoques de Combustíveis, no que tange a obrigatoriedade de mistura de biodiesel ao diesel mineral, garante aos produtores um mercado competitivo para vendas e aos consumidores a disponibilidade de biocombustível com antecedência e a menores preços (LOCATELLI, 2008).

Neste contexto e diante da convicção do papel fundamental que os leilóes possuem no mercado de biodiesel, entender a maneira como está sendo conduzido e os resultados gerados por ele são importantes. Estudos recentes acerca do mercado nacional de biodiesel não têm abordado, de maneira específica, os leilóes realizados pela ANP, tornando os resultados destes uma base de dados ainda pouco explorada. Assim sendo, a partir de análises sobre os leilóes, faz-se o seguinte questionamento: quais fatores influenciaram a evolução do mercado brasileiro de biodiesel, sob a ótica da oferta deste produto nos leilóes realizados pela ANP?

De forma geral, esse trabalho busca identificar e estudar os fatores que influenciaram a evolução do mercado brasileiro de biodiesel sob a ótica da oferta deste produto nos leilóes públicos realizados pela ANP. Especificamente, pretende-se:

a) Descrever a evolução da produção de biodiesel no Brasil, detalhar as principais 
variações comportamentais do mercado e verificar o cumprimento das principais funções do sistema;

b) Analisar a estrutura de mercado que melhor delineia o setor de biodiesel;

c) Detectar e caracterizar os fatores que mais influenciaram para a formação da estrutura de mercado do biodiesel.

Este artigo está organizado em seis seções, contados com a introdução. Na seção II apresenta-se a fundamentação teórica sobre teoria dos leilóes, concentração de mercado e descrição sobre o biodiesel e seu programa. A seção III trata dos leilões de comercialização de biodiesel. Os materiais e métodos propostos estão apresentados na seção IV. Na seção V aplicam-se os índices de concentração industrial e o modelo de regressão linear múltipla. Na seção VI estão apresentadas as conclusões do estudo.

\section{Fundamentação Teórica}

\subsection{Teoria dos Leilões}

Remontando aos anos 500 a.C., os leilões são considerados como um mecanismo de negociação de bens e serviços regido pela lei da oferta e da demanda, em que o preço é obtido pelo melhor lance oferecido pelos interessados participantes. $\mathrm{O}$ caso mais simples de leilão acontece quando se tem interesse em vender um determinado bem e há mais de um comprador em potencial. Esse aumento da concorrência, juntamente com eficiência econômica, solução para alocação de excesso de oferta e conveniência administrativa são razões que impulsionam a introdução do uso dos leilões (REGO, 2012).

São incontáveis os tipos e formatos de leilões, porém quatro modelos são considerados clássicos pela literatura geral por generalizarem uma estrutura básica. São eles:

a) Leilão Inglês: é a forma mais comum de oferecimento de lances em um leilão. Neste, o leiloeiro estabelece um preço mínimo inicial, abaixo do qual a unidade não poderá ser vendida. A partir deste preço, lances excedentes vão se sucedendo, com conhecimento de todos, até que nenhum participante proponha uma oferta maior, vencendo aquele que propôs a última oferta.

b) Leilão Holandês: não é comumente utilizado na prática. Neste, o leiloeiro inicia a oferta a um preço exorbitante, acima da sua melhor expectativa. A partir daí anuncia-se um novo preço menor que o enunciado na oferta anterior. Este procedimento é repetido até que algum participante se manifeste, levando o bem pelo lance ofertado.

c) Leilão Discriminatório: são também denominados de leilão de primeiro preço. Neste, os lances são únicos por participante e são feitos em envelopes lacrados. Posteriormente à realização de todas as ofertas, os envelopes são abertos e vence o leilão quem tiver ofertado o maior preço, pagando-o pelo bem.

d) Leilão de Vickrey: são também denominados de leilão de segundo preço. Neste, os lances são únicos por participante e são feitos em envelopes lacrados. Posteriormente à realização de todas as ofertas, os envelopes são abertos e vence o leilão quem tiver ofertado o maior preço, pagando, porém, o segundo maior lance do leilão pelo bem.

No que tange à estratégia adotada por cada participante na hora de colocar os seus lances no leilão, pode-se afirmar que os quatro leilões são equivalentes, pois o lance ótimo de cada participante sempre será algo inferior ao valor que ele atribuiu ao objeto. No que diz respeito à receita que cada tipo de leilão deve gerar para o vendedor do objeto ou para o leiloeiro, afirma-se que a expectativa para qualquer dos tipos de leilão também é a mesma. Esse é um resultado clássico denominado Teorema de Equivalência de Receitas (POLYDORO, 2014). 


\subsection{Concentração industrial}

A concentração industrial, oriunda de estudos referentes à Organização Industrial, é visualizada como um dos determinantes estruturais mais relevantes da competição, pois, de acordo com a teoria econômica neoclássica, uma indústria mais concentrada, constituída por um pequeno número de grandes firmas, prejudica a competição (KON, 1994).

Feijo, Carvalho e Rodriguez (2003), por sua vez, trata a concentração industrial como:

"um processo que consiste no aumento do controle exercido pelas grandes empresas sobre a atividade econômica. O grau de concentração é uma medida que sintetiza a estrutura produtiva, uma vez que incorpora tanto aspectos tecnológicos relacionados ao porte quanto à consolidação do poder de mercado de um setor" ( p. 22).

A estrutura de mercado à qual um setor pertence é de suma importância para o estabelecimento de suas estratégias e políticas de preços por parte das firmas, uma vez que essas implicarão em seu desempenho. Esse conjunto teórico originou-se em 1930, quando Edward S. Mason propôs o esquema descritivo da relação entre variáveis da indústria e o seu desempenho, denominado Estrutura-Conduta-Desempenho (ECD). Dentro deste paradigma, propõe-se uma relação de causalidade única entre estrutura (nível de concentração) e conduta (grau de conluio), e entre conduta e desempenho (rentabilidade) (AMIRALIAN, 1998).

No modelo ECD, o desempenho é consequência de aspectos como: práticas e políticas de preços, linhas de produtos e estratégias de divulgação, investimento em técnicas de produção, entre outros. A conduta depende da estrutura predominante no mercado, caracterizada por número e tamanho de ofertantes e demandantes (concentração), pela presença ou ausência de barreiras à entrada de novas firmas e pelo grau de integração vertical das firmas.
Além disso, a estrutura é influenciada por características básicas do lado da oferta e da demanda, quais sejam: localização da matéria-prima, grau de tecnologia, durabilidade do produto, elasticidade preço da demanda e bens substitutos. Todas essas variáveis são influenciadas pelas condições básicas de oferta, demanda e políticas públicas (COSTA e GARCIAS, 1998).

Assim, a concentração torna-se um indicador de fundamental importância na classificação da estrutura de um determinado mercado, sendo cada estrutura diferenciada de acordo com o grau de concentração existente, medidos a partir dos índices de concentração industrial (LEITE, 1998).

Para Leite (1998), os índices de concentração fornecem elementos empíricos através dos quais se torna possível analisar o nível de competição em uma indústria e estabelecer comparativos com segmentos semelhantes em diferentes mercados. Isto é, quanto maiores forem os índices de concentração, menor é o grau de concorrência entre as empresas e, portanto, mais concentrado estará o poder de mercado - monopólio. Do contrário, maior o grau de concorrência entre as firmas - concorrência perfeita.

\subsection{Biodiesel no Brasil}

$\mathrm{O}$ amplo leque de benefícios socioambientais advindos do biodiesel fez surgir, em 06 de dezembro de 2004, o Programa Nacional de Produção e Uso de Biodiesel (PNPB) que objetiva implantar, de forma sustentável, tanto técnica, quanto economicamente, a produção e uso do biodiesel com enfoque na inclusão social e no desenvolvimento regional (MME, 2014).

O Programa foi oficialmente instalado com o Decreto Presidencial n. 5.297, de 6 de dezembro de 2004, com as seguintes principais diretrizes:

- Implantar um programa sustentável, promovendo inclusão social;

- Garantir preços competitivos, qualidade e suprimento;

- Produzir o biodiesel a partir de diferentes fontes oleaginosas e em regióes diversas. 
No entanto, a institucionalização do PNPB veio apenas em 13 de janeiro de 2005 com a Lei n. 11.097, cuja matéria versava sobre a criação do PNPB, a introdução do biodiesel na matriz energética brasileira, a ampliação da competência administrativa da ANP que passou a compreender também as atividades relacionadas aos biocombustíveis, além do estabelecimento de percentuais mínimos de mistura compulsória do biodiesel ao diesel mineral e dos prazos a partir dos quais vigorariam tais percentuais (ALVARENGA JÚNIOR e YOUNG, 2013).

A mistura de biodiesel ao diesel fóssil teve início em dezembro de 2004, em caráter autorizativo. Em janeiro de 2008, entrou em vigor a mistura legalmente obrigatória de $2 \%$ (B2) em todo o território nacional. Com o perceptível amadurecimento do mercado brasileiro, esse percentual foi ampliado pelo Conselho Nacional de Política Energética (CNPE) sucessivamente até atingir 5\% (B5) em janeiro de 2010, antecipando em três anos a meta estabelecida, prevista para 2013. Em 28 de maio de 2014, a Medida Provisória n. 647 alterou o percentual obrigatório do biodiesel misturado ao óleo diesel comercializado ao consumidor final, passando de $5 \%$ para $6 \%$ a partir de 1o de julho. Com a MP n. 647, ficou estabelecido ainda que este percentual chegaria a $7 \%$ a partir de $1^{\text {o }}$ de novembro de 2014 , podendo, por motivo justificado de interesse público, ser reduzido a qualquer tempo para até 5\%, restabelecendo-o quando da normalização das condições que motivaram a redução do percentual (ANP, 2014).

A gestão do PNPB é realizada pela Comissão Executiva Interministerial do Biodiesel (Ceib), coordenada pela Casa Civil da Presidência da República, a qual possui, como unidade executiva, um Grupo Gestor (GG), coordenado pelo Ministério de Minas e Energia (MME). Assim, compete à Ceib elaborar, implementar e monitorar um programa integrado, propor os atos normativos que se fizerem necessários à implantação do programa, assim como analisar, avaliar e propor outras recomendações e ações, diretrizes e políticas públicas. Ao Grupo Gestor compete a execução das ações relativas à gestão operacional e administrativa voltadas para o cumprimento das estratégias e diretrizes estabelecidas pela Ceib (MME, 2014).

Seguindo a orientação de inclusão social e desenvolvimento regional do PNPB, criou-se o Selo Combustível Social (SCS), um componente de identificação criado a partir do Decreto n. 5.297, de 06 de dezembro de 2004, que vem desempenhando um papel de certificação de projetos que estejam alinhados com os anseios do governo federal no que tange à participação dos agricultores familiares, enquadrados no Programa Nacional de Fortalecimento da Agricultura Familiar (Pronaf), na cadeia produtiva do biodiesel (ALVARENGA JÚNIOR e YOUNG, 2013). No entanto, Araújo (2013) afirma que,

\footnotetext{
"apesar da grande quantidade de indústrias que obtêm o Selo Combustível Social, este não é um indicativo da inserção da agricultura familiar na produção de biodiesel" (p. 23).
}

O principal efeito advindo do SCS tem sido o de permitir às indústrias de biodiesel a desoneração total ou parcial de tributos federais e o acesso às menores taxas de juros na concessão de créditos para financiamento de suas atividades produtivas junto aos bancos e instituições credenciadas (IPEA, 2012).

\section{Leilões de biodiesel}

O sistema de leilões públicos foi escolhido pelo governo federal para assegurar o adequado funcionamento do sistema de estoques do biodiesel, advindo do progressivo aumento da mistura obrigatória do biocombustível ao diesel. Este funciona como um mecanismo transparente de comercialização de biodiesel que garante aos produtores e aos agricultores um mercado competitivo para a venda da produção e, aos consumidores, a disponibilidade de biocombustível com antecedência e a menores preços, vez que o risco dos produtores é menor por já saberem o quanto poderão vender (LOCATELLI, 2008). 
Para Mendes e Costa (2009), a comercialização de biodiesel via leilóes garante ainda: igualdade na disputa entre pequenos e grandes produtores de biodiesel; eliminação ou minimização da assimetria de informação entre os agentes; fornecimento de um ambiente competitivo entre os produtores; facilidade na fiscalização do cumprimento do percentual de mistura do biodiesel ao diesel mineral e participação da agricultura familiar no fornecimento de matérias-primas para a produção de biodiesel.

Os leilões, promovidos desde 2005 pela ANP, são realizados por sistema reverso, ou seja, é estabelecido um Preço Máximo de Referência (PMR), por região, e os ofertantes apresentam propostas de preços menores pelos quais aceitam vender seu produto.

Tal sistema apresenta o benefício de permitir que se pague o menor preço possível (aceito pelo produtor) pelo produto em negociação, o que o caracteriza como do tipo menor preço, isto é, aqueles que ofertam um menor preço do bem ganha o leilão. No entanto, este preço deve estar abaixo do preço máximo de referência definido pela Agência (LOCATELLI, 2008).

As diretrizes gerais para a realização de leilóes públicos para aquisição de biodiesel, em razão das obrigatoriedades legais previstas, foram edi- tadas pelo CNPE na Resolução n. 05, de 03 de outubro de 2007. As diretrizes específicas para os leilões de compra de biodiesel, por sua vez, foram apresentadas a partir da Portaria MME n. 284, de 04 de outubro de 2007, com alteração fixada pela Portaria MME n. 301, de 20 de outubro de 2007, substituída pela Portaria MME n. 109, de 17 de março de 2008. Novas alterações ocorreram com a Portaria n. 274, de 26 de abril de 2011, modificada pela Portaria n. 469, de 02 de agosto de 2011, a qual foi revogada pela Portaria MME n. 276, de 10 de maio de 2012. Com sua revogação, entrou em vigor o "novo modelo" de leilões, da Portaria MME n. 476, de 15 de agosto de 2012, válido até os dias atuais.

Quanto à periodicidade, nos modelos e regras anteriores, o que determinava se um leilão iria ocorrer era a necessidade que a ANP observava no mercado de obter mais produto frente a um aumento de demanda. No novo, os leilóes passaram a ocorrer bimestralmente e com a periodicidade e antecedência necessárias para assegurar o adequado suprimento do mercado consumidor. Além do que ficou aberta a possibilidade para que, no futuro, adote-se a periodicidade mensal.

Fazendo um aparato geral, têm-se as principais diferenças entre os modelos antigos e o vigente, conforme Quadro 1.

Quadro 1. Mudanças nos sistemas de leilões públicos da ANP

\begin{tabular}{|l|l|}
\hline \multicolumn{1}{|c|}{$\begin{array}{c}\text { Portaria MME n. 276, de 10 de maio de } 2012 \\
\text { “ANTIGO” }\end{array}$} & \multicolumn{1}{c|}{$\begin{array}{c}\text { Portaria MME n. 476, de 15 de agosto de 2012 } \\
\text { "NOVO” }\end{array}$} \\
\hline Leilões realizados em quatro etapas. & Leilões realizados em seis etapas. \\
\hline Leilões promovidos diretamente pela ANP. & Leilóes promovidos direta ou indiretamente pela ANP. \\
\hline Leilões com periodicidade indefinida. & Leilões com periodicidade definida. \\
\hline Leilões com adquirentes passivos. & Leilões com adquirentes ativos. \\
\hline Leilões com lances presenciais. & Leilões com lances on-line. \\
\hline Leilões com volume adquirido definido pelo MME. & Leilões com volume adquirido definido pela distribuidora. \\
\hline Leilões com lotes indivisíveis. & Leilões com lotes divisíveis. \\
\hline Leilões com único ganhador por lote. & Leilões com múltiplos ganhadores por lote. \\
\hline Leilões com capacidade ofertada igual à capacidade instalada. & Leilões com capacidade ofertada maior à capacidade instalada. \\
\hline Leilões com preço FOB + FAL. & Leilões com preço FOB - FAL. \\
\hline Leilões com Preço Máximo de Referência dados por leilão. & Leilões com Preço Máximo de Referência dados por região. \\
\hline
\end{tabular}

Fonte: Elaboração própria, a partir das Portarias MME n. 276/2012 e n. 476/2012. 
Figura 1. Etapas dos leilões públicos de biodiesel

\begin{tabular}{|l|l|}
\hline Etapa $\mathbf{1}$ (nova) & Habilitação dos fornecedores \\
\hline Etapa 2 & Apresentação das ofertas pelos fornecedores \\
\hline Etapa 3 & Seleção das ofertas pelos adquirentes, com origem exclusiva em fornecedores com SCS \\
\hline Etapa 4 (nova) & Reapresentação de preços das ofertas pelos fornecedores \\
\hline Etapa 5 & Seleção das demais ofertas pelos adquirentes com origem em quaisquer fornecedores \\
\hline Etapa 6 & Consolidação e divulgação do resultado final \\
\hline
\end{tabular}

Fonte: Elaboração própria, a partir da Portaria MME n. 476, de 15 de agosto de 2012.

Mais detalhadamente, no sistema instituído pela Portaria MME n. 476/2012, os leilóes passaram a ser promovidos em seis etapas principais a partir da introdução de duas novas (Figura 1).

No modelo anterior a 2012, os leilóes eram presenciais com duas rodadas de lances e as ofertas eram classificadas pela ANP para posterior apresentação aos produtores e importadores de óleo diesel. No modelo atual, os fornecedores apresentam seus lances pela internet, com uso de sistema eletrônico específico para esta finalidade e baseado na plataforma de compra da Petrobras, a Petronect. No modelo anterior, a usina definia a região de destino observando o Fator de Ajuste Logístico - planilha de cálculo do preço do biocombustível considerando os custos do transporte interestadual e inter-regional - com a finalidade de equilibrar regionalmente a produção. No modelo novo, a usina não define mais a região de destino, sendo o produto ofertado sempre "na porta da usina".

\section{Metodologia}

Trata-se de um estudo de natureza exploratória, descritiva e explicativa em que são levantados e analisados os dados que retratam a evolução dos leilões de biodiesel promovidos pela ANP.
Para atingir os objetivos propostos no trabalho a metodologia foi dividida em oito etapas. $\mathrm{Na}$ primeira, foi feito o delineamento da pesquisa, a estruturação do problema, a contextualização e a definição dos objetivos.

$\mathrm{Na}$ segunda etapa, foi realizado o levantamento bibliográfico, a revisão dos principais conceitos e o aprofundamento teórico sobre o tema.

$\mathrm{Na}$ terceira etapa, foram obtidos os dados dos leilões de biodiesel entre 2005 e 2014, inclusive. O levantamento desses elementos, tanto qualitativos quanto quantitativos, se deu por meio do cruzamento de informações secundárias, porém oficiais, disponibilizadas em sites divulgados pelo Ministério do Desenvolvimento Agrário (MDA) e pela Agência Nacional de Petróleo, Gás Natural e Biocombustíveis (ANP), além de um sólido levantamento em teses, dissertações, artigos científicos e livros que sustentam as análises realizadas.

A delimitação temporal do estudo corresponde ao período de criação e implantação do sistema de leilóes para a comercialização de biodiesel em 2005. Assim, foram considerados todos os editais para outorga de concessão licitada até dezembro de 2014. O Edital ANP 56/14, referente ao quadragésimo leilão não foi considerado devido a não efetivação do certame ainda nesse ano. 
Na quarta etapa, os dados coletados foram tabulados em planilha do Microsoft Excel $^{\circledR}$ de maneira a formar o banco de dados.

Na quinta etapa, foram feitas observações da evolução dos fatores que compõem o mercado, tais como: volumes arrematado e ofertado, preços máximo e médio, deságios, empresas e regiões participantes. Isso, junto a informações existentes sobre o biodiesel e resultados das análises comentadas, permitiu verificar o comportamento evolutivo do setor desde a implantação do mecanismo de leilóes.

$\mathrm{Na}$ sexta etapa, foram realizados os cálculos referentes aos índices de concentração, sendo os mais comuns e utilizados no trabalho o índice de Razão de Concentração (CR), o índice de Hirschman-Herfindahl $(\mathrm{HH})$ e o índice de Entropia de Theil (TH).

O CR determina a participação de grandes empresas no mercado a partir da seguinte equação:

$$
C R(k)=\sum_{i=1}^{k} S_{i}
$$

em que $s_{i}$ representa a participação da empresa no total do mercado e $k$ é o número da amostra das maiores empresas.

Nesse trabalho, foi considerada a participação das duas, quatro e oito maiores empresas. As respectivas razões de concentração são conhecidas como CR(2), CR(4) e CR(8).

Para a análise do grau de concentração do mercado utilizou-se a classificação proposta por Leonardi, Scarton e Padula (2010), com algumas alterações:

- CR inferior a 0,35: mercado com baixa concentração;

- CR entre 0,35 e 0,65: mercado com média concentração;

- CR igual ou superior a 0,65: mercado com alta concentração.

O índice de Hirschman-Herfindahl determina a participação de grandes empresas no mercado potencializando suas participações relativas a partir da elevação de cada parcela ao quadrado. A sua verificação é possível com a seguinte equação:

$$
H H=\sum_{i=1}^{n}\left(s_{i}\right)^{2}
$$

em que $s_{i}$ representa a participação da empresa no total do mercado e $n$ é o número total de empresas.

Segundo a Federal Trade Commission dos Estados Unidos, ao aplicar o $\mathrm{HH}$, existem três linhas de corte que balizam e classificam o grau de concentração de um mercado:

- HH inferior a 0,1: mercado com baixa concentração;

- HH entre 0,1 e 0,18: mercado com média concentração;

- HH igual ou superior a 0,18: mercado com alta concentração.

O índice de Entropia de Theil determina a participação de grandes empresas no mercado perante o uso de logaritmo. Este é representado por:

$$
T H=\sum_{i=1}^{n} S_{i} \cdot \ln \left(1 / s_{i}\right)
$$

em que $s_{i}$ representa a participação da empresa no total do mercado, $n$ é o número total de empresas e ln é o logaritmo natural.

Por corresponder o contrário da concentração, na avaliação deste foi considerado o seguinte:

- TH inferior a 1,5: mercado com alta concentração;

- TH entre 1,5 e 2,5: mercado com média concentração;

- TH igual ou superior a 2,5: mercado com baixa concentração.

Vale ressaltar ainda que todos os índices foram mensurados com base no volume arrematado pelas empresas em cada leilão, medido em metros cúbicos. Além disso, foram considerados os grupos empresariais e não cada unidade de modo separado. Isso significa que empresas que possuem mais de uma unidade produtiva tiveram seus dados somados, de modo a facilitar o entendimento das análises realizadas.

Os produtos finais advindos dessa análise foram: a verificação da evolução dos níveis de concentração do setor e a formação da estrutura de mercado que melhor o delineia. 
Na sétima etapa, foi realizada a Regressão Linear Múltipla a partir do método dos Mínimos Quadrados Ordinários. O objetivo para o emprego desta foi detectar e quantificar os fatores que mais influenciaram os índices de concentração, vez que estes são determinantes para a formação da estrutura de mercado, como predito.

Dentre os índices de concentração industrial, o Hirschman-Herfindahl foi o utilizado para a análise, por ser, segundo Resende (1994), a medida mais conveniente para comparações intertemporais. A operacionalização do modelo foi realizada com o auxílio do pacote estatístico StataCorp LP, versão 12.0. Este software foi escolhido devido à sua adequação ao propósito desta pesquisa e à já comprovada utilização por outros pesquisadores, quanto à realização de análises econométricas.

Assim, os efeitos das variáveis explicativas na variável dependente foram verificados a partir da estimação do modelo abaixo.

$$
\begin{aligned}
& H H=\beta_{0}+\beta_{1} E M+\beta_{2} M I+\beta_{3} A N+ \\
& +\beta_{4} V O+\beta_{5} P R+\beta_{6} V A+\mu_{i}
\end{aligned}
$$

em que $H H$ é a variável dependente representada pelo índice de concentração de Hirschman-Herfindahl. As variáveis independentes, ou explicativas, por sua vez, são o número de empresas ofertantes $(E M)$, o percentual de mistura obrigatório $(M I)$, o decorrer dos anos $(A N)$, o volume arrematado $(V O)$, o preço máximo de referência $(P R)$ e o valor total arrematado $(V A)$. Essas foram escolhidas por serem consideradas indispensáveis em análises sobre os leilões de biodiesel. $\beta$ representam os parâmetros a serem estimados e, $\mu_{i}$ o termo de erro, que visa a possibilidade de existirem outras variáveis, além das supracitadas, capazes de afetarem o índice de concentração.

A oitava e última etapa consistiu no confronto de dados para analisar o mercado de biodiesel a partir dos resultados do estudo e conclusões afins.

\section{Resultados e discussão}

\subsection{Análise geral do mercado}

Com o intuito de descrever a evolução da produção do biodiesel, detalhar as principais variações comportamentais e verificar o cumprimento das principais funções do sistema de leilões será realizada, nesta seção, a análise geral do mercado de biodiesel no Brasil, a partir da observação dos principais fatores que compõem o mercado, tais como: volumes arrematado e ofertado, preços máximo e médio, deságios, empresas e regiões participantes.

No período de 2005 a 2014 foram realizados 40 leilóes de biodiesel - sendo um complementar - com um total de aproximadamente $22.664 .620 \mathrm{~m}^{3}$ ofertados, dos quais $17.902 .458 \mathrm{~m}^{3}$ foram arrematados, ou seja, 78,99\% do total. Assim, pode-se concluir que os leilões vêm cumprindo suas principais funções de comercialização e abastecimento.

A evolução dos volumes ofertados e arrematados nos leilões está apresentada na Figura 2, a seguir.

Além disso, observou-se que as regiões Centro-Oeste e Sul se destacaram no volume arrematado dos leilóes do período entre 2005 e 2014, com 40,55\% e 30,26\% do total (Figura 3). 
Figura 2. Volumes ofertados e arrematados nos leilóes de biodiesel da ANP

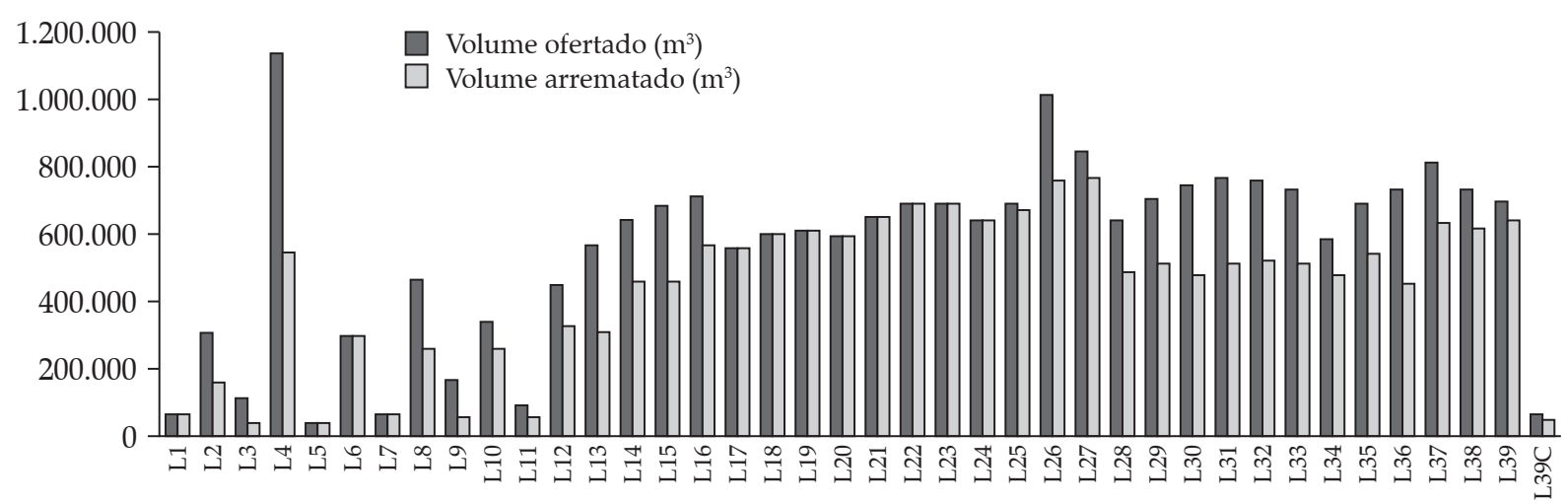

Fonte: Elaboração própria, a partir de dados disponibilizados pela ANP.

Figura 3. Volumes arrematados nos leilões de biodiesel da ANP, por região

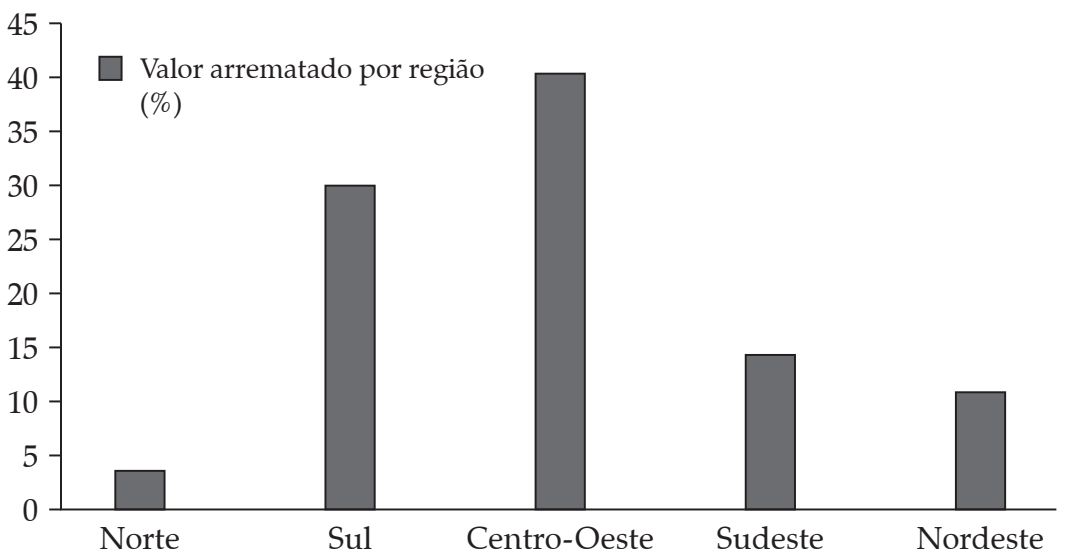

Fonte: Elaboração própria, a partir de dados disponibilizados pela ANP.

O principal motivo dessa centralização deve-se ao fato que essas regiões contêm a maior parte das indústrias instaladas de biodiesel das 58 plantas autorizadas para operação em 2014 no Brasil, 44,34\% encontram-se na região Centro-Oeste e $34,49 \%$, na região Sul. As indústrias escolhem essas regiões por serem as mais próximas dos fatores locacionais considerados determinantes para a viabilidade da produção, como a proximidade do mercado fornecedor de matéria-prima - são as maiores produtoras brasileiras de soja, principal matéria-prima para produção de biodiesel - e a proximidade do mercado consumidor de biodiesel. Assim, pode-se concluir que o parque industrial do biodiesel está concentrado nas regiões Centro-Oeste e Sul do Brasil.

Ao analisar os dados da Figura 4 tem-se que os valores arrematados nos dez anos de leilóes da ANP não foram sempre crescentes, tendo uma queda abrupta em 2007 , de $44,81 \%$, e uma queda menor, de $2,43 \%$, em 2014 , em relação aos anos anteriores. A possível causa da queda ocorrida em 2007 foi a utilização da modalidade de pregão 
Figura 4. Valores arrematados nos leilóes de biodiesel da ANP, por ano

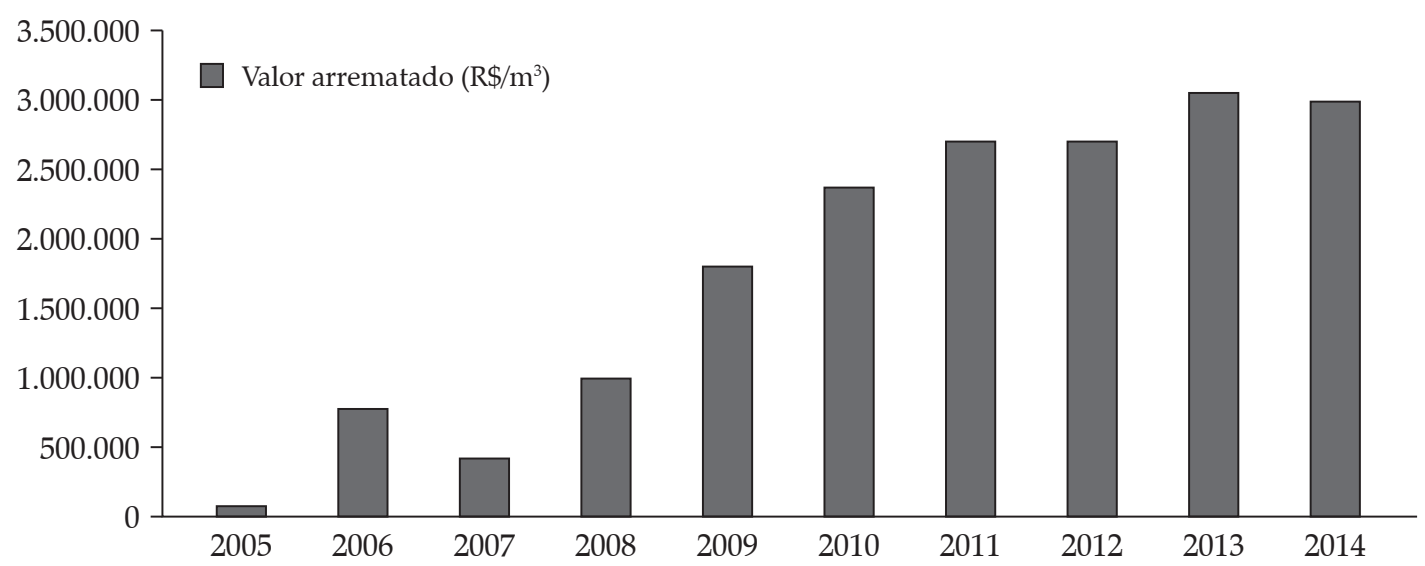

Fonte: Elaboração própria, a partir de dados disponibilizados pela ANP.

eletrônico "ComprasNet", a qual não contribuiu para aprimorar a competitividade esperada para os leilões e ainda foi considerada pelas usinas como uma ferramenta muito ampla, pouco flexível e que não atendia às necessidades específicas do comércio de biodiesel.

Ademais, os 40 leilóes de biodiesel em conjunto perfizeram um total de, aproximadamente, $\mathrm{R} \$ 38.885 .504 .368,12$ sobre as vendas entre $2005 \mathrm{e}$ 2014, considerando a margem do adquirente.
Para a formação do Preço Máximo de Referência (PMR) do biodiesel, a ANP utiliza o valor do óleo de soja como parâmetro, visto que esta é a principal matéria-prima utilizada no processo de produção do biodiesel. A Figura 5 apresenta a evolução dos PMR da ANP, e a Figura 6 a evolução das cotações do óleo de soja, observadas a partir da Bolsa de Chicago.

A evolução das cotações do óleo de soja é observada a partir da Bolsa de Chicago.

Figura 5. Preços máximos de referência dos leilões de biodiesel da ANP

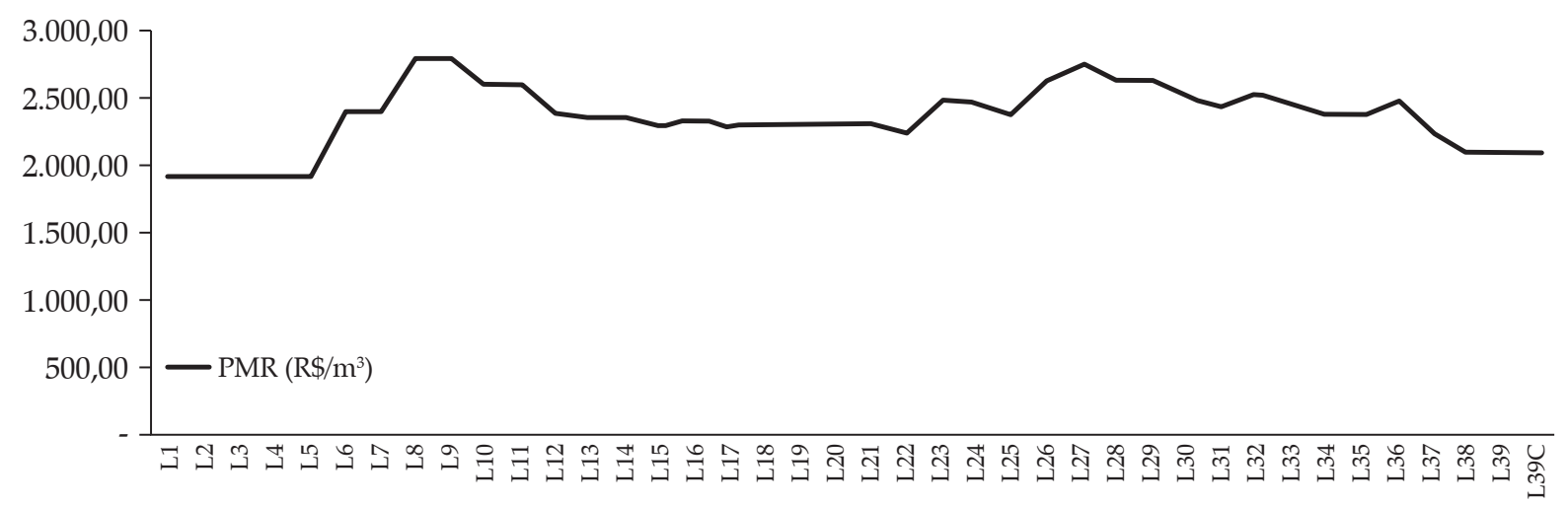

Fonte: Elaboração própria, a partir de dados disponibilizados pela ANP. 
Figura 6. Cotações do óleo de soja

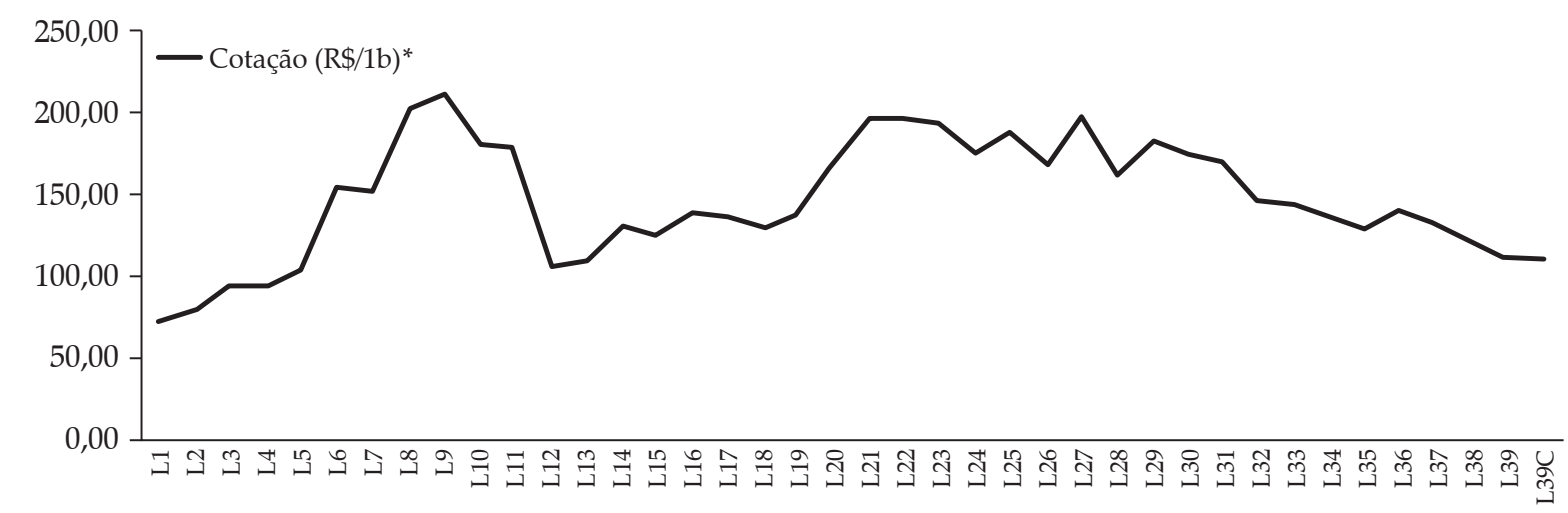

* Os valores foram convertidos em reais (R\$) com base na cotação média mensal de junho/2016.

Fonte: Elaboração própria, a partir de dados disponibilizados pelo IEA.

Analisadas em conjunto, as Figuras 5 e 6 permitem a comparação entre o PMR do biodiesel e a cotação do óleo de soja. Considerando apenas os leilões de 2014 para constatação, verificou-se que, quando houve uma valoração ou desvalorização no preço do óleo de soja, o mesmo ocorreu com o preço do biodiesel nos leilóes, porém não vis-à-vis

Assim, conclui-se que a formação do preço de referência da ANP apresenta o mesmo movimento que o preço do óleo de soja, mas essa variabilidade é sempre melhor para o preço do biodiesel de modo a torná-lo mais competitivo. Analisando a evolução dos preços médios rece- bidos pelos produtores de biodiesel, percebe-se, ainda, uma movimentação similar deste com a movimentação dos PMR (Figura 7).

Outrossim, a diferença entre o preço médio e o preço máximo de referência médio é chamada de "ágio" ou "deságio" pelos participantes dos leilões de biodiesel. Assim sendo, significativos "deságios" foram verificados nos leilões de biodiesel da ANP, com exceção do 390 leilão. Neste, o preço médio do volume arrematado foi de $R \$$ $2.104,00 / \mathrm{m}^{3}$, o que significou um "ágio" médio de 0,67\% quando comparado ao preço máximo de referência médio do leilão, de $\mathrm{R} \$ 2.090,00 / \mathrm{m}^{3}$.

Figura 7. Preços médios dos leilões de biodiesel da ANP

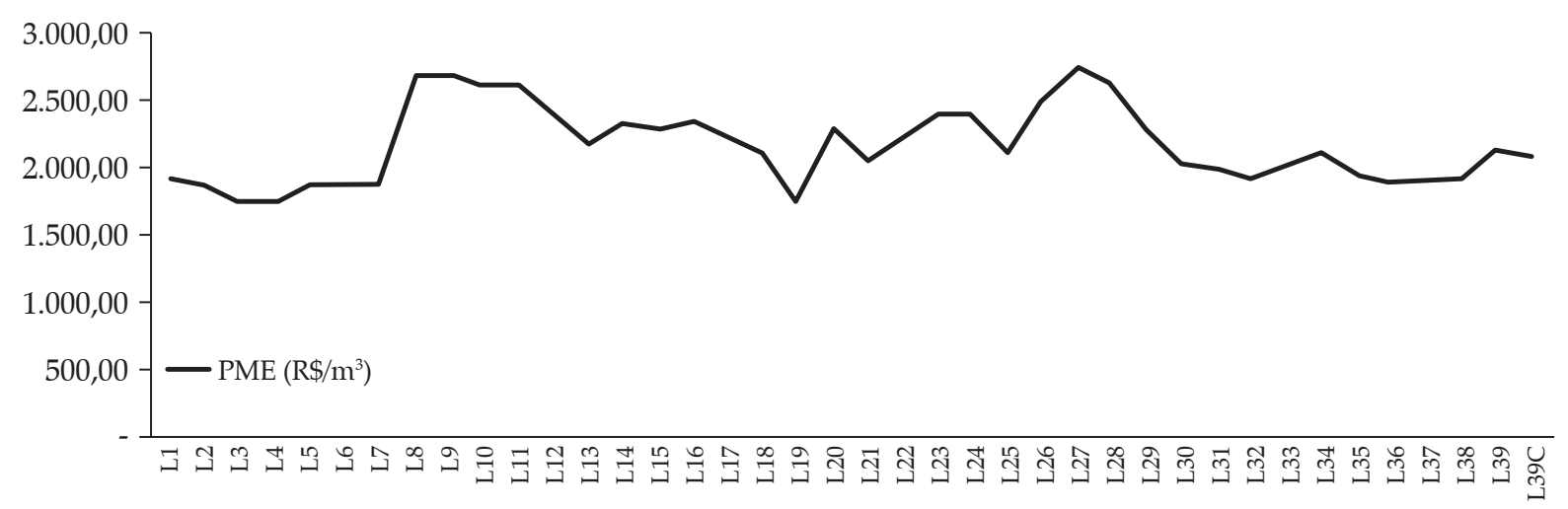

Fonte: Elaboração própria, a partir de dados disponibilizados pela ANP. 
Figura 8. Deságios médios dos leilões de biodiesel da ANP

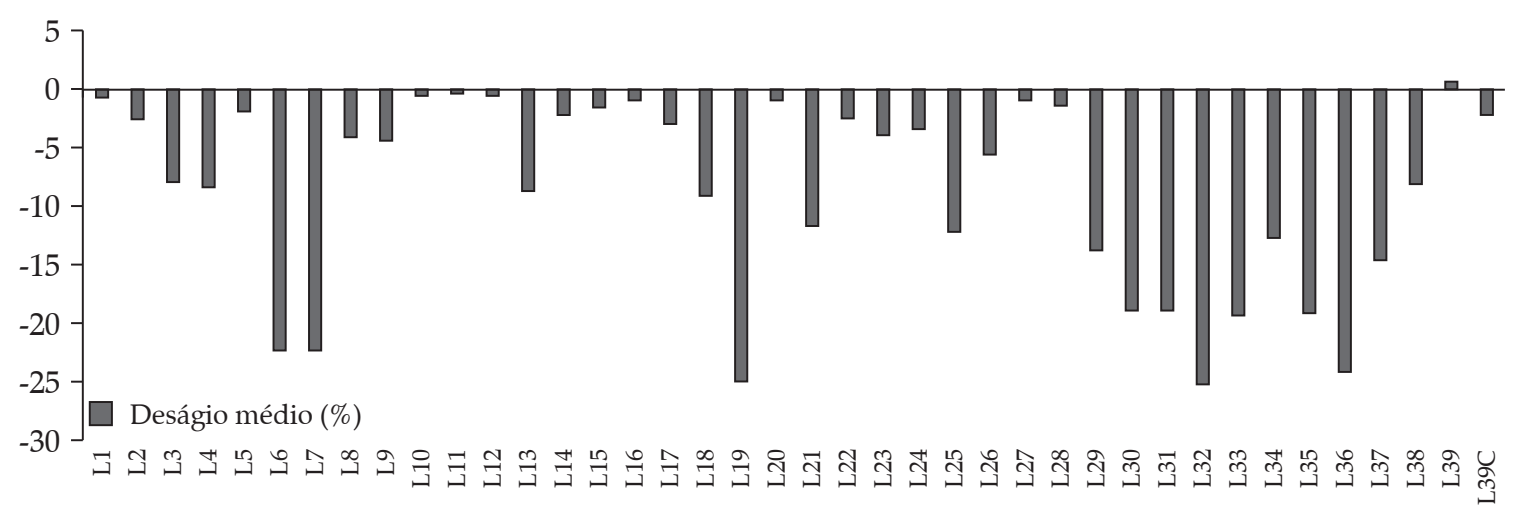

Fonte: Elaboração própria, a partir de dados disponibilizados pela ANP.

Tal fato ocorreu porque diante de uma oferta de biodiesel mais próxima à demanda, os adquirentes tinham expectativas que os lotes fossem arrematados a preços mais elevados, aumentando, assim, a disposição a pagar mais. No entanto, não foi isso que aconteceu porque a ANP, na hora do leilão, considerou que a oferta de produto pelas usinas era pequena e resolveu "dividir" o volume a ser arrematado em dois leilões, transferindo $25 \%$ da demanda para o outro leilão complementar.

A Figura 8 apresenta a evolução dos deságios médios observados ao longo dos leilóes realizados pela ANP.

Ainda considerando os dados da Figura 8, depreendeu-se que a modalidade de negociação dos leilões teve grande influência na geração dos "deságios". Por exemplo, do $8^{\circ}$ ao $18^{\circ}$ leilão, marcados pelos menores "deságios" do período, foi utilizada a modalidade de leilão presencial, que permitia a minimização de práticas predatórias por parte das empresas, uma vez que as ofertas foram realizadas em envelopes fechados. Com a introdução dos leilões eletrônicos, em que existe a disputa de preços por parte dos ofertantes, os deságios aumentaram. Como exemplo, cita-se o período inicial dos leilóes em que as ofertas eram dadas pelo sistema Licitações-e do Banco do Brasil e o período compreendido entre o $29^{\circ}$ e o $39^{\circ}$ leilão em que as ofertas foram dadas pela modalidade de leilão público.

\subsection{Análise de concentração de mercado}

Com o objetivo de caracterizar a estrutura de mercado que melhor delineia o setor de biodiesel no Brasil, três índices de concentração foram calculados: índice de Razão de Concentração para as duas maiores empresas - CR(2), para as quatro maiores empresas - CR(4), e para as oito maiores empresas - CR(8); índice de Hirschman-Herfindahl e índice de Entropia de Theil. A análise dos dois primeiros índices fundamentou-se no pressuposto de que se a repartição da parcela de mercado das empresas for elevada, haverá concentração. O terceiro índice, por sua vez, fundamentou-se no pressuposto contrário, isto é, se a repartição da parcela de mercado das empresas for elevada, haverá desconcentração. Os parâmetros utilizados para avaliação de tais índices constam na seção 4 deste trabalho.

O comportamento das Razões de Concentração para as duas, quatro e oito maiores empresas do setor, mostra que os níveis de concentração referentes às participações das empresas nos leilões de biodiesel diminuíram consideravelmente com o passar dos leilóes (Figura 9). Para exemplificar esta situação, basta a constatação de que no 
Figura 9. Concentração de mercado do biodiesel - CR

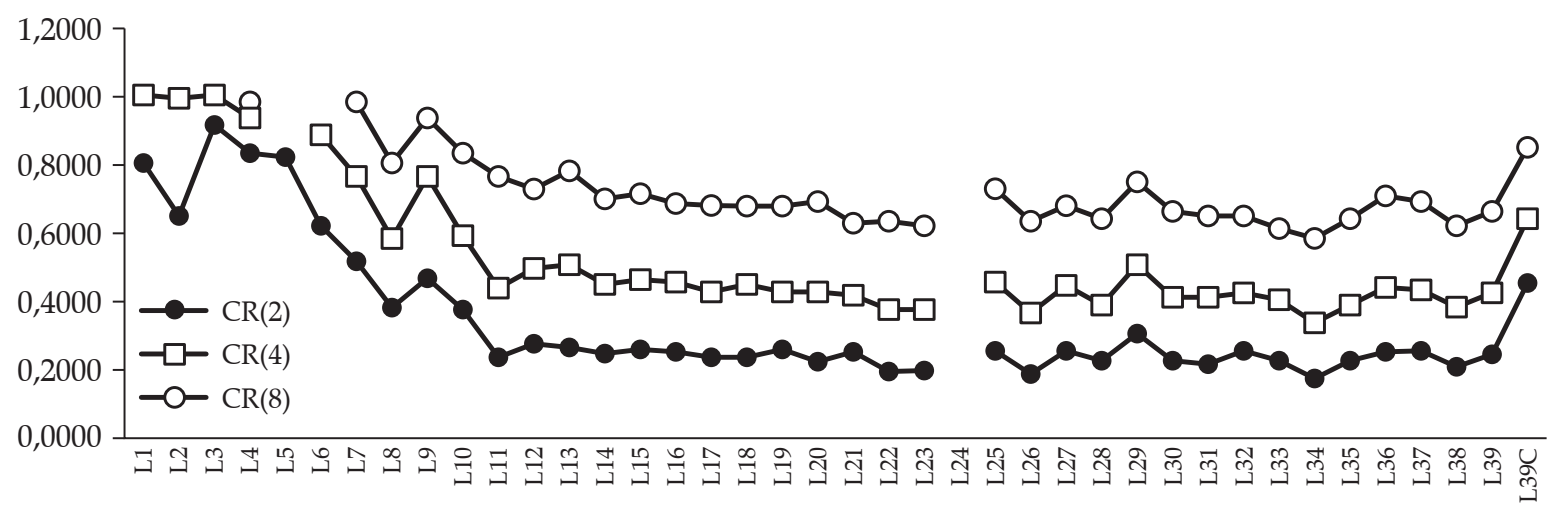

Fonte: Elaboração própria, a partir de dados disponibilizados pela ANP.

primeiro leilão realizado o $\mathrm{CR}(2)$ foi de $0,8043 \mathrm{e}$, no $39^{\circ}$, de $\mathrm{CR}(2)=0,2457$. Isto é, uma redução de $227 \%$ nos níveis de concentração.

Considerando a classificação proposta por Leonardi, Scarton e Padula (2010), o CR(2) para todos os leilões em conjunto caracterizou o mercado em baixa concentração, com índice de 0,3503 . Ou seja, juntas, as duas maiores empresas do setor representaram $35,03 \%$ do market-share. O CR(4) para os leilões considerados foi de 0,5283 , o que caracterizou o mercado em moderadamente concentrado nas quatro maiores empresas do setor. Isto é, $52,83 \%$ da participação de mercado é de responsabilidade das quatro maiores empresas do setor. $\mathrm{O} C R(8)$ para todos os leilões conjuntamente caracte- rizou o mercado com alta concentração, com índice de 0,7198. Ou seja, juntas, as oito maiores empresas do setor representaram $71,98 \%$ do market-share.

Pela mensuração do índice de Hirschman-Herfindahl $(\mathbf{H H})$, inferiu-se um movimento de desconcentração do setor aliado à diminuição representativa da desigualdade na distribuição das parcelas de mercado entre as empresas, conforme apresentado na Figura 10. Para verificação, basta a constatação de que no primeiro leilão realizado, o HH foi de 0,3836 e, no 39º, de 0,1378, o que caracteriza mercado com alta concentração no primeiro e com moderada concentração no último. Entre 2005 e 2014, os níveis de concentração baixaram em $437 \%$.

Figura 10. Concentração de mercado do biodiesel - HH

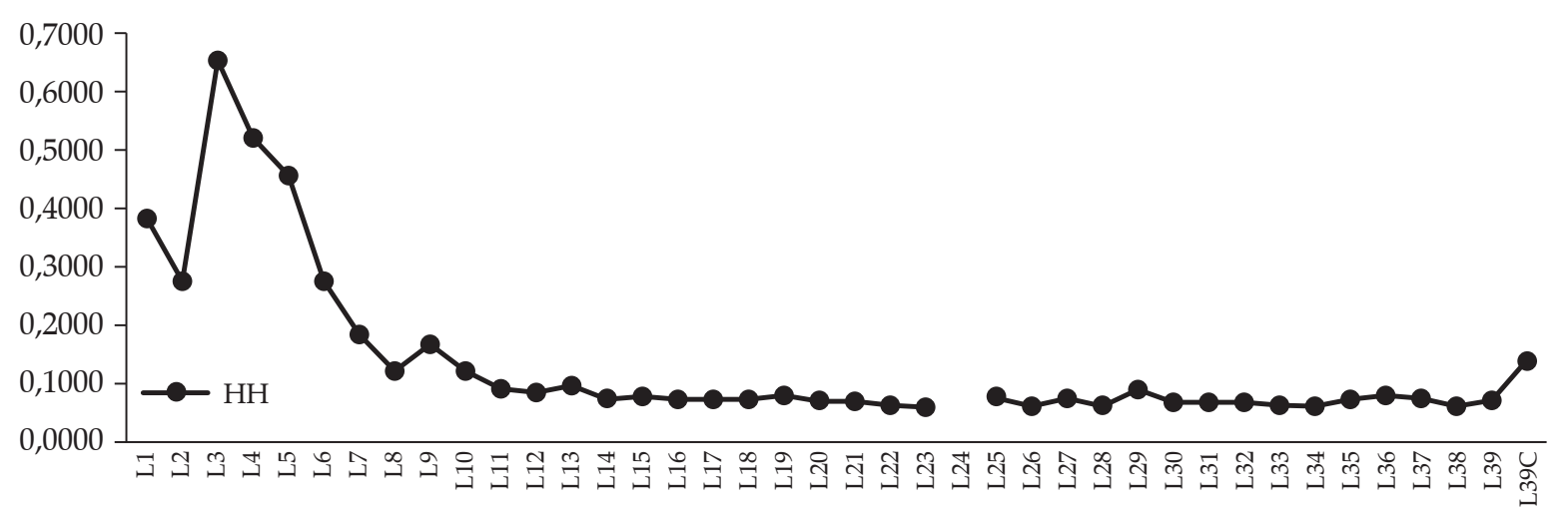

Fonte: Elaboração própria, a partir de dados disponibilizados pela ANP. 
Considerando a classificação da Federal Trade Comission, o índice HH para todos os leilóes de biodiesel caracterizou o mercado com moderada concentração, com índice de 0,1374.

O comportamento dos indicadores $\mathrm{CR}$ e $\mathrm{HH}$ e TH são inversamente proporcionais, uma vez que o CR e o HH medem o grau de concentração de um mercado, enquanto o TH mede o grau de desconcentração do mesmo. Assim sendo, o coeficiente de Entropia de Theil (TH) da análise mostrou que os níveis de concentração (desconcentração) também caíram (aumentaram) (Figura 11). Para comprovar isso, fez-se a comparação entre o primeiro leilão $(\mathrm{TH}=1,1300)$ e o $39^{\circ}$ ( $\mathrm{TH}$ $=2,8699$ ), que apresentaram um aumento nos níveis de desconcentração de $154 \%$.

Todos os índices estudados mostraram uma sucessiva e elevada desconcentração do setor no decorrer dos leilões. Porém, observou-se maior oscilação nos primeiros leilões, em que o sistema ainda estava em fase de adaptação. A partir do 11으 leilão, os níveis de concentração se tornaram menores e mais estáveis, apresentando modificações mínimas na média dos índices de concentração. A Tabela 1 apresenta o agrupamento dos resultados dos índices de concentração analisados para todo o período compreendido entre 2005 e 2014.

A partir das estimativas dos índices de concentração CR(2), CR(4), CR(8), HH e TH expostos na Tabela 1, e da literatura estudada, evidenciou-se que se trata de um índice atual de concentração moderado entre as maiores empresas participantes e de um setor industrial caracterizado pelo oligopólio como estrutura de mercado. Mais especificamente, trata-se de um oligopólio puro e

Figura 11. Concentração de mercado do biodiesel - TH

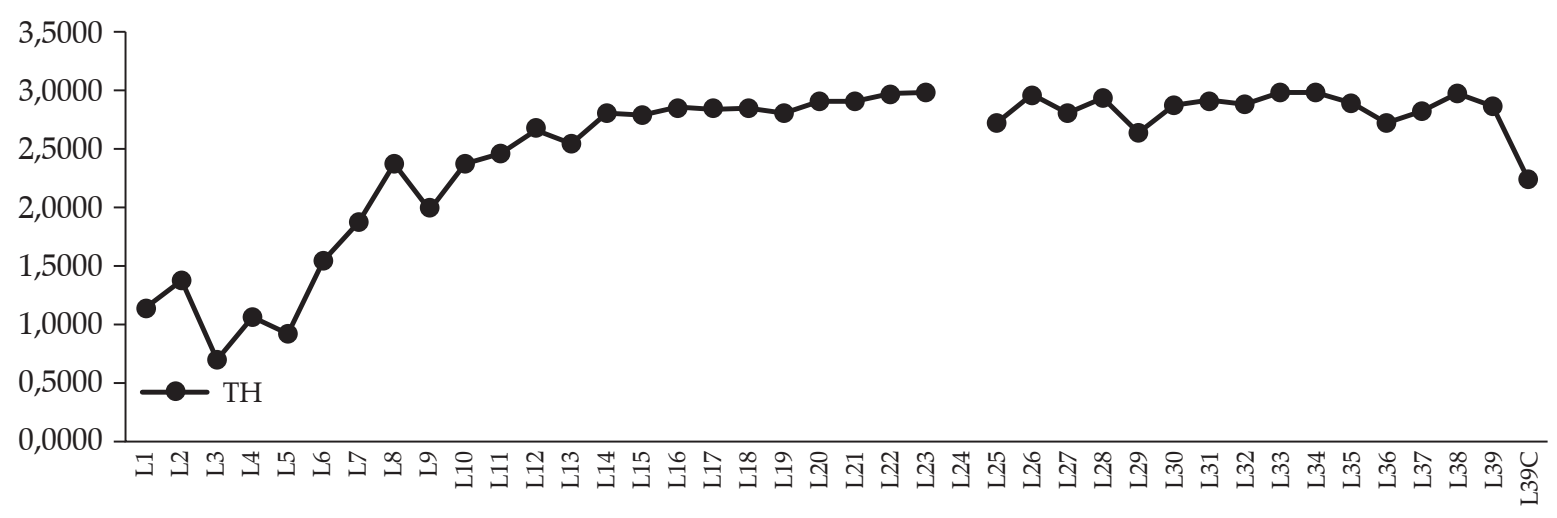

Fonte: Elaboração própria, a partir de dados disponibilizados pela ANP.

Tabela 1. Resultados dos índices de concentração dos leilões de biodiesel da ANP

\begin{tabular}{ccc}
\hline Índice de Concentração & Valor Médio & Avaliação \\
\hline $\mathrm{CR}(2)$ & 0,3503 & Mercado com baixa concentração \\
$\mathrm{CR}(4)$ & 0,5283 & Mercado com média concentração \\
$\mathrm{CR}(8)$ & 0,7198 & Mercado com alta concentração \\
$\mathrm{CR}$ & $\mathbf{0 , 5 3 2 8}$ & Mercado com média concentração $^{1}$ \\
HH & $\mathbf{0 , 1 3 7 4}$ & Mercado com média concentração $^{2}$ \\
TH & $\mathbf{2 , 4 8 8 7}$ & Mercado com média concentração $^{3}$ \\
\hline
\end{tabular}

Notas: 1. Baseado em Leonardi, Scarton e Padula (2010); 2. Baseado em Federal Trade Comission; 3. Baseado em parâmetros de análises já realizadas.

Fonte: Elaboração própria, a partir dos resultados da análise. 
concentrado moderadamente, tendo as seguintes características:

a) o grau de concentração de mercado é moderado tanto a nível técnico, ou seja, ao nível das plantas produtivas, quanto ao nível econômico. Desta forma, algumas empresas são responsáveis pela maior parte da produção;

b) há barreiras à entrada devido aos vários requisitos que devem ser atendidos pelas empresas produtoras do biocombustível, além dos fatores logísticos;

c) os produtos não são diferenciados, ou seja, são homogêneos, em que a diferenciação, quando existe, se dá ao nível da qualidade ou das especificações dos produtos;

d) os preços são mantidos invariáveis, pois são estabelecidos pela ANP. Com isso, há pouca probabilidade de que a concorrência via preços seja a forma utilizada para eliminar concorrentes e aumentar a fatia de mercado;

e) importantes descontinuidades de escala e de técnicas de produção permitem a coexistência de empresas de variados tamanhos e, em consequência, de diferentes níveis de custo de produção.

\subsection{Análise de influência dos fatores}

A tendência de desconcentração do setor de biodiesel no Brasil, a evidência de mercado moderadamente concentrado e um setor industrial caracterizado pelo oligopólio como estrutura de mercado suscitaram a necessidade de verificar quais fatores influenciaram tais definições. Isto é, buscou-se averiguar o que proporcionou essa desconcentração sucessiva e, mais precisamente, qual o real impacto desses fatores nos índices e, consequentemente, na estruturação de mercado.

Pindyck e Rubinfeld (2002), afirmam que as teorias são desenvolvidas para explicação de fenômenos, sendo necessárias para construir modelos do problema estudado, a partir dos quais são realizadas previsões. Para tanto, utiliza-se de análise positiva, que consiste em proposições de causa e efeito. A análise de Regressão Linear Múltipla (RLM) é um dos inúmeros modelos estatísticos causais referentes ao tratamento de séries temporais de dados, e pode também ser utilizada para a avaliação dos efeitos das variáveis explicativas como previsoras das variáveis de resposta. Assim, a presente dissertação utilizou um modelo estatístico de regressão linear múltipla, em que foi testada a explicação sobre uma variável $Y$ dependente, em função de diversas variáveis independentes $\mathrm{X}$ simultaneamente.

Assim, ajustando os dados ao modelo de Regressão Linear Múltipla, obtiveram-se os seguintes resultados:

O primeiro resultado consiste na interpretação dos coeficientes de regressão, do erro padrão, do Teste t e do P-valor. Estes dados constam na Tabela 2.

Tabela 2. Resultados da RLM

\begin{tabular}{ccccc}
\hline Preditor & Coeficiente & Erro Padrão & Teste $\mathbf{t}$ & $\begin{array}{c}\text { Probabilidade de significância } \\
\text { (P-valor) }\end{array}$ \\
\hline Constante & $-24,0075$ & 18,8529 & $-1,27$ & 0,212 \\
EM & $-0,0082$ & 0,0019 & $-4,14$ & 0,000 \\
MI & $-0,0426$ & 0,0173 & $-2,45$ & 0,020 \\
NA & 0,0124 & 0,0094 & 1,32 & 0,197 \\
VO & 1,1798 & 2,2501 & 0,52 & 0,604 \\
PR & $-0,0002$ & 0,0001 & $-3,93$ & 0,000 \\
VA & $-0,00004$ & 0,00009 & 0,41 & 0,688 \\
\hline
\end{tabular}

Fonte: Elaboração própria, a partir de dados disponibilizados pela ANP. 
A equação de regressão para os fatores de influência dos níveis de concentração foi definida como:

$$
\begin{aligned}
& H H=-24,0075-0,0082 E M-0,0426 M I+ \\
& +0,0124 A N+1,1798 V O-0,0002 P R- \\
& -0,00004 V A
\end{aligned}
$$

A função dos coeficientes determinados pela regressão linear múltipla foi indicar como alterações unitárias em cada variável independente podem influenciar o valor da variável dependente, principal foco desta análise.

Além disso, a Tabela 2 mostra o resultado do teste de significância para os coeficientes parciais individuais, denominado Teste t. O questionamento essencial deste teste é se o valor atribuído a cada coeficiente é significativamente diferente de 0 ou se tal valor ocorreu simplesmente ao acaso. Para o modelo em estudo, o Teste $t$ significou que, num intervalo de confiança de $95 \%$, a equação de regressão teve três variáveis independentes positivamente correlacionadas ( $\mathrm{AN}, \mathrm{VO}$ e $\mathrm{VA})$ e três negativamente correlacionadas (EM, MI e PR) entre si e com a variável dependente $\mathrm{HH}$. Tal fato não implica no simples descarte das variáveis positivamente relacionadas, mas confere a estas um baixo nível de significância.

Verificou-se, também, por meio dos P-valor da Tabela 2, que as variáveis AN, VO e VA não exerceram influências sobre a variável independente $(\mathrm{HH})$, vez que apresentaram P-valor $>0,05$. Sinteticamente, os coeficientes de EM, MI e PR são estatisticamente significativos a menos de $5 \%$. Os coeficientes de AN, VO, VA e da Constante só são significativos acima de $10 \%$.
Assim sendo, a equação estimada assumiu a seguinte forma:

$H H=-0,0082 E M-0,0427 M I-0,0002 P R$

$\mathrm{O}$ segundo resultado apresentado pela regressão linear múltipla foi o teste de significância global do modelo de previsão da variabilidade da variável dependente $(\mathrm{HH})$ em função das variáveis independentes. O propósito do Teste $\mathrm{F}$ é determinar a confiança que pode ser depositada nos resultados da regressão e a sua aplicabilidade na população de valores possíveis.

O grau de significância apurado pelo Teste $\mathrm{F}$ para as variáveis independentes preditoras, EM, MI e PR, foi 0,0000, menor do que $5 \%$, mostrando que a variável dependente $(\mathrm{HH})$ pode ser explicada conjuntamente pelas variáveis independentes (EM, MI e PR). Além disso, o valor de F calculado foi de 29,54, que é maior que o valor de $\mathrm{F}$ tabelado, a 6 graus de liberdade no numerador e 32 no denominador $(3,47$ a 1\%, 5\% e $10 \%$ de significância). Logo, pode-se dizer que o resultado da equação de regressão foi significativo, pois os coeficientes foram estatisticamente significativos em conjunto.

$\mathrm{O}$ resultado do Teste $\mathrm{F}$ da regressão pode ser visualizado na Tabela 3.

O terceiro resultado do modelo foi o resumo do modelo de regressão, o qual indicou se o mesmo foi capaz de prever a variabilidade da variável dependente em função das variáveis independentes. A Tabela 4 apresenta esses resultados.

Tabela 3. Teste F da RLM

\begin{tabular}{lccccc}
\hline & SQ & GL & MQ & Teste F & F de significação \\
\hline Regressão & 0,6264 & 6 & 0,1044 & 29,54 & 0,000 \\
Resíduo & 0,1131 & 32 & 0,0035 & - & - \\
Total & 0,7395 & 38 & 0,1946 & - & - \\
\hline
\end{tabular}

Fonte: Elaboração própria, a partir de dados disponibilizados pela ANP.

Tabela 4. Estatísticas da RLM

\begin{tabular}{ccc}
\hline $\mathbf{R}$ múltiplo & $\mathbf{R}^{2}$ & $\mathbf{R}^{2}$ ajustado \\
\hline 0,9204 & 0,8471 & 0,8184 \\
\hline
\end{tabular}

Fonte: Elaboração própria, a partir de dados disponibilizados pela ANP. 
O R múltiplo é a medida de inter-relação entre a variável dependente e a variável independente, também chamado de coeficiente de correlação. Ele pode variar de 0 (que indica ausência de correlação) a \pm 1 (que indica correlação perfeita). Nesse modelo, R múltiplo foi igual a 0,9204 , o que indicou uma forte correlação entre $\mathrm{HH}$ e todas as variáveis explanatórias - independentes - em conjunto.

O coeficiente de determinação identificado por $\mathrm{R}^{2}$ é uma estimativa de qualidade do modelo que pode assumir valores entre 0 e 1 , sendo o último o que representa a situação em que toda a variação é explicada. No modelo, $\mathrm{R}^{2}$ foi igual a 0,8471 , o que significou que $84,71 \%$ da variação no índice de concentração $(\mathrm{HH})$ foi explicada pela variação combinada de número de empresas ofertantes (EM), percentual de mistura obrigatória (MI) e preço de referência (PR).

A medida $R^{2}$ ajustado é utilizada como estimativa de aderência, indicando o quanto um modelo pode ser generalizado. $\mathrm{O}$ ideal é que esta diferença seja igual a zero. $\mathrm{O}$ valor de $\mathrm{R}^{2}$ ajustado constante da Tabela 4 foi igual a 0,8184. A diferença entre os $R^{2}$ e $R^{2}$ ajustado foi igual a 0,0287 .
Logo, a proximidade dessas estimativas mostra que o modelo é confiável e foi bem ajustado aos dados, sendo um modelo muito bom para a explicação de HH.

Após a análise de RLM, o modelo foi exposto à verificação de Heterocedasticidade. Para isso, dois testes foram realizados: o teste de Breusch-Pagan e o teste de White. No primeiro, considerando a hipótese nula, H0: homocedasticidade e a hipótese alternativa, H1: heterocedasticidade, a um nível de significância de $5 \%$, rejeitou-se a hipótese de homocedasticidade; isto é, há uma grande dispersão nos dados apresentados. No teste de White, considerando as mesmas hipóteses, o valor de $\mathrm{P}=0,77$ ficou acima do nível de significância, demonstrando que o modelo não possui heterocedasticidade. Surgiu, então, um problema: enquanto o teste de Breusch-Pagan acusou heterocedasticidade, o teste de White mostrou o inverso. De qualquer forma, foi feita a Correção Robusta de White para correção dos erros. As Tabelas 5, 6 e 7 demonstram os novos resultados obtidos com a correção da heterocedasticidade.

Tabela 5. Resultados da RLM depois da Correção Robusta de White

\begin{tabular}{ccccc}
\hline Preditor & Coeficiente & Erro Padrão Robusto & Teste t & $\begin{array}{c}\text { Probabilidade de signifi- } \\
\text { cância (P-valor) }\end{array}$ \\
\hline Constante & $-24,0075$ & 13,2293 & $-1,81$ & 0,079 \\
EM & $-0,0082$ & 0,0011 & $-7,27$ & 0,000 \\
MI & $-0,0426$ & 0,0136 & $-3,14$ & 0,004 \\
NA & 0,0124 & 0,0067 & 1,86 & 0,072 \\
VO & 1,1798 & 2,15 & 0,55 & 0,587 \\
PR & $-0,0002$ & 0,0001 & $-2,94$ & 0,006 \\
VA & $-0,00004$ & 0,00008 & 0,47 & 0,642 \\
\hline
\end{tabular}

Fonte: Elaboração própria, a partir de dados disponibilizados pela ANP.

Tabela 6. Teste F da RLM depois da Correção Robusta de White

\begin{tabular}{lccccc}
\hline & SQ & GL & MQ & Teste F & F de significação \\
\hline Regressão & 0,6263 & 6 & 0,1044 & 14,99 & N/D \\
Resíduo & 0,1131 & 32 & 0,0035 & - & - \\
Total & 0,7394 & 38 & 0,1079 & - & - \\
\hline
\end{tabular}

Fonte: Elaboração própria, a partir de dados disponibilizados pela ANP.

Tabela 7. Estatísticas da RLM depois da Correção Robusta de White

\begin{tabular}{ccc}
\hline R múltiplo & $\mathbf{R}^{2}$ & $\mathbf{R}^{2}$ ajustado \\
\hline 0,9204 & 0,8471 & 0,8471 \\
\hline
\end{tabular}

Fonte: Elaboração própria, a partir de dados disponibilizados pela ANP. 
A equação de RLM passou ser a seguinte:

$\mathrm{HH}=-24,00751-0,00817 \mathrm{EM}-$

$-0,04257 \mathrm{MI}+0,0124 \mathrm{AN}-0,00020 \mathrm{PR}$

Logo, o modelo possuiu também tanto a "Constante" quanto o coeficiente de "AN" estatisticamente significativos. Assim, o aumento em um ano provoca um efeito positivo em $\mathrm{HH}$ de 0,0124 .

Segundo os resultados da Tabela 6, todos os coeficientes foram estatisticamente significativos em conjunto, pois o valor da estatística $\mathrm{F}(14,99)$ foi maior que qualquer valor $\mathrm{F}$ tabelado a $1 \%, 5 \%$ e $10 \%$ com 6 graus de liberdade no numerador e 32 no denominador.

A Tabela 7 mostra que a qualidade do ajustamento ( $\mathrm{R}^{2}$ ajustado) do modelo também melhorou, agora de $84,71 \%$, explicitando o quanto as variações em $\mathrm{HH}$ são explicadas pelas variáveis EM, MI, AN e PR. $R^{2}$ ajustado alcançou o considerado nível ideal para uma análise de regressão, isto é, que a diferença entre $\mathrm{R}^{2}$ e $\mathrm{R}^{2}$ ajustado foi igual a zero.

Em suma, a análise estatística revelou que, das seis variáveis independentes do modelo anteriormente apresentadas, duas - VO e VA - não apresentaram evidências estatísticas de influência na variabilidade do índice de concentração $(\mathrm{HH})$. Por outro lado, as variáveis independentes: número de empresas ofertantes (EM), percentual de mistura obrigatório (MI), decorrer dos anos (AN) e preço máximo de referência (PR) apresentaram evidências estatísticas da sua influência na formação dos índices de concentração. No entanto, como buscou-se os fatores que influenciaram o processo de desconcentração do setor, AN não foi considerado.

Assim, conclui-se que a quantidade de empresas participantes dos leilóes (EM), o aumento dos percentuais de mistura obrigatório de biodiesel ao diesel mineral (MI) e o preço máximo de referência de cada leilão (PR) foram os principais fatores que influenciaram o processo de desconcentração do setor de biodiesel no Brasil entre 2005 e 2014, e consequentemente, a formação da estrutura oligopolista de mercado. Mais especificamente, teve-se que o índice de concentração $\mathrm{HH}$ diminuiu:

- $0,0082(0,82 \%)$ para cada unidade de acréscimo no número de empresas participantes;

- $0,0426(4,26 \%)$ para cada acréscimo no percentual de mistura obrigatório;

- 0,0002 (0,02\%) para cada unidade de milhar acrescida no preço máximo de referência.

\section{Conclusões}

Entre o período de 2005 a 2014 foram realizados 40 leilóes de biodiesel - sendo um complementar - com um total de $22.664 .620 \mathrm{~m}^{3}$ ofertados, dos quais $17.902 .458 \mathrm{~m}^{3}$ foram arrematados, perfazendo um total de $\mathrm{R} \$ 38.885 .504 .368,12$, conforme dados da Agência Nacional do Petróleo, Gás Natural e Biocombustíveis (ANP). Tais dados permitiram inferir que os leilóes vêm cumprindo suas principais funções de comercialização e abastecimento do setor.

$\mathrm{Na}$ análise da estrutura de mercado que melhor delineia o setor de biodiesel foi verificado que, inicialmente, o mercado de biodiesel no Brasil era mais concentrado, tanto pela menor quantidade de empresas habilitadas, quanto pelas suas capacidades limitadas de competir num período inicial de produção. Com o decorrer dos leilões, elevação de preços e ascensão da capacidade demandada devido ao aumento do percentual de mistura obrigatório exigido por lei, a quantidade de empresas participantes com capacidade de produzir e participar dos leilões se elevou, indicando melhor distribuição das parcelas de mercado e, consequentemente, maior desconcentração no setor. As estimativas dos índices de concentração CR(2), CR(4), CR(8), HH e TH indicaram uma concentração de mercado moderada para todo o setor industrial no período estudado, o que permitiu caracterizá-lo como um mercado oligopolista puro, em que os produtos não são diferenciados, algumas empresas são responsáveis pela maior parte da produção e há barreiras à entrada devido às várias exigências que devem ser cumpridas pelas empresas. 
Diante dos testes estatísticos realizados no modelo econométrico, verificou-se que a variação no número de empresas participantes (EM), o aumento dos percentuais de mistura obrigatórios (MI) e as mudanças nos preços máximos de referência (PR) foram os principais influenciadores no processo de desconcentração do setor de biodiesel e, consequentemente, na formação da estrutura oligopolista de mercado.

Assim, quando se observa o mecanismo de leilóes de biodiesel, nota-se que estes poderão assegurar preços competitivos por parte das empresas, evitar a formação de cartéis, obrigar as empresas a comprarem de agricultores familiares para obter o SCS, além de controlar os níveis de concentração do mercado. No entanto, os problemas sociais, ambientais e econômicos ainda existentes no PNPB e no SCS persistem enfatizando a necessidade de contínuo acompanhamento da evolução dos resultados dos leilões, com o objetivo de desenvolver novos métodos de análises e propor melhorias no sistema, para que os leilões se tornem efetivamente um sistema eficiente e, seus resultados, cada vez mais transparentes para a sociedade.

\section{Referências}

ALVARENGA JÚNIOR, M. e YOUNG, C. E. F. Produção de biodiesel no Brasil, inclusão social e ganhos ambientais. In: IV Encontro Latinoamericano de Economia da Energia (ELAEE), 2013, Montevideo. IV Encontro Latinoamericano de Economia da Energia (ELAEE). Montevideo: ELAEE, 2013.

ANP. Agência Nacional do Petróleo, Gás Natural e Biocombustíveis. Boletim Mensal do Biodiesel: mês de agosto de 2014. 2014. Disponível em: <http://www.anp. gov.br > . Acesso em: 05 set 2014.

CASTELLANELLI, C. A. Estudo da viabilidade de produção do biodiesel, obtido através do óleo de fritura usado, na cidade de Santa Maria - RS. 2008. 112 f. Dissertação (Mestrado em Engenharia de Produção) - Programa de PósGraduação Engenharia de Produção, Universidade Federal de Santa Maria, Santa Maria, 2008.

FEIJO, C. A., CARVALHO, P. G. M. e RODRIGUEZ, M. S. Concentração industrial e produtividade do trabalho na indústria de transformação nos anos 90: evidências empíricas. Economia (Campinas), Rio de Janeiro, v. 4, n.Jan-Jun03, p. 19-52, 2003.

IPEA. Instituto de Pesquisa Econômica Aplicada. Biodiesel no Brasil: desafios das politicas públicas para a dinamização da produção. Comunicados do IPEA, Brasília, n.137, mar. 2012. 22 p.

KON, A. Economia industrial. São Paulo: Nobel, 1994.

LEITE, A. L. S. Índices de concentração na indústria de papel e celulose. In: Encontro Nacional de Engenharia de Produção 98, 1998. Anais do Encontro Nacional de Engenharia de Produção 1998, 1998. v. 18. p. 1-8.

LEONARDI, A., SCARTON, L. M. e PADULA, A. D. A concentração do mercado de biodiesel no brasil. In: $48^{\mathrm{o}}$ Evento da SOBER - Sociedade Brasileira de Economia, Administração e Sociologia Rural, 2010, Campo Grande - MS. 48o Evento da SOBER - Sociedade Brasileira de Economia, Administração e Sociologia Rural: Tecnologias, Desenvolvimento e Integração Social, 2010.

LOCATELLI, V. A inserção da agricultura familiar no Programa Nacional de Produção e Uso do Biodiesel e as demandas socioambientais das suas representações, 2008. 110 f. Dissertação (Mestrado em Gestão e Planejamento Ambiental) - Programa de Pós-Graduação Stricto Sensu em Gestão e Planejamento Ambiental, Universidade Católica de Brasília. Brasília, 2008.

MENDES, A. P. A. e COSTA, R. C. da. Mercado brasileiro de biodiesel e perspectivas futuras. BNDES Setorial, Rio de Janeiro, n. 31, p. 253-280, nov. 2009.

MME. Ministério de Minas e Energia. Portaria no ${ }^{0} 76$, de 15 de agosto de 2012.

. Programa Nacional de Produção e Uso de Biodiesel. 2014. Disponível em: <http://www.mme.gov.br>. Acesso em: 25 jun. 2014.

PINDYCK, R. S. e RUBINFELD, D. L. Microeconomia. 6 ed. São Paulo: Pearson Prentice Hall, 2005.

POLYDORO, A. Introdução à teoria de leilões e sua aplicação aos leilões de EEP. Cadernos FGV Energia. Maio 2014, ano 1, no 01, p. 30-35, 2014.

REGO, E. E. Proposta de aperfeiçoamento da metodologia dos leilóes de comercialização de energia elétrica no ambiente regulado: aspectos conceituais, metodológicos e suas aplicações. 2012. 248 f. Tese (Doutorado em Ciências) - Programa de Pós-Graduação em Energia, Escola Politécnica / Faculdade de Economia, Administração e Contabilidade / Instituto de Eletrotécnica e Energia / Instituto de Física, Universidade de São Paulo, São Paulo, 2012. 
RESENDE, M. Medidas de concentração industrial: uma resenha. Revista Análise Econômica, Faculdade de Ciências Econômicas, ano 11, no 21 e 22, p. 24-33, mar./ set. 1994.

SILVEIRA, J. H. M. D. da., SILVA, S. B. e SILVA JÚNIOR., V.S. da. Energia renovável e impacto ambiental. Bolsista de
Valor: Revista de divulgação do Projeto Universidade Petrobras e IF Fluminense, v. 1, p. 85-90, 2010.

ZANELLA, B. UFPel produz biodiesel à base de sebo bovino. Diário Popular via Internet. Pelotas, 26 ago. 2007. Disponível em: <http://srv-net.diariopopular.com. br/26_08_07/p1201.html>. Acesso em: 29 jan. 2013. 
